\title{
The genus Luticola (Bacillariophyta) on Ile Amsterdam and Ile Saint-Paul (Southern Indian Ocean) with the description of two new species
}

\author{
Barbora CHATTOVÁ ${ }^{1, *}$, Marc LEBOUVIER ${ }^{2}$, \\ Myriam DE $\mathrm{HAAN}^{3} \&$ Bart VAN DE VIJVER ${ }^{3,4}$ \\ ${ }^{1}$ Department of Botany \& Zoology, Faculty of Science, Masaryk University, \\ Kotlarska 2, 61137 Brno, Czech Republic. \\ ${ }^{2}$ UMR 6553 Ecobio CNRS, Université de Rennes 1, Station Biologique, \\ F-35380 Paimpont, France. \\ ${ }^{3}$ Botanic Garden Meise, Research Department, \\ Domein van Bouchout, B-1860 Meise, Belgium. \\ ${ }^{4}$ University of Antwerp, Department of Biology, ECOBE, \\ Universiteitsplein 1, B-2610 Wilrijk, Belgium. \\ "Corresponding author: barbora.chattova@gmail.com \\ ${ }^{2}$ Email: marc.lebouvier@univ-rennes1.fr \\ ${ }^{3}$ Email: myriam.dehaan@plantentuinmeise.be \\ ${ }^{3,4}$ Email: bart.vandevijver@plantentuinmeise.be
}

\begin{abstract}
Five species of the terrestrial diatom genus Luticola D.G.Mann were found during a taxonomic survey of two small volcanic islands, Ile Amsterdam and Ile Saint-Paul (Southern Indian Ocean). Apart from the two already known Luticola species L. beyensii Van de Vijver et al. and L. subcrozetensis Van de Vijver et al., two new species are described: L. ivetana Chattová \& Van de Vijver sp. nov. and L. vancampiana Chattová \& Van de Vijver sp. nov. Finally, one, up to now unknown, Luticola species is briefly discussed and illustrated. Detailed morphological descriptions of these taxa are provided based on both light and scanning electron microscopy observations. Morphological features of the new species are compared to morphologically similar taxa, and notes on their ecology and biogeography are added.
\end{abstract}

Keywords. Bacillariophyta, diatoms, Luticola, new species, morphology.

Chattová B., Lebouvier M., de Haan M. \& Van de Vijver B. 2017. The genus Luticola (Bacillariophyta) on Ile Amsterdam and Ile Saint-Paul (Southern Indian Ocean) with the description of two new species. European Journal of Taxonomy 387: 1-17. https://doi.org/10.5852/ejt.2017.387 


\section{Introduction}

The genus Luticola D.G.Mann is one of the dominant genera in the Antarctic terrestrial diatom flora. Luticola taxa can be distinguished in having uniseriate striae, composed of rounded to transapically elongated areolae covered internally by perforated hymenes, a usually distinct isolated pore in the central area, a longitudinal canal positioned within the valve wall and by a simple, filiform raphe with variable raphe endings (Round et al. 1990; Levkov et al. 2013). However, the correct taxonomy and biogeography of this genus in the sub-Antarctic region was hampered due to species drift and force fitting the Antarctic species into European and North American names (Tyler 1996). Due to the lack of appropriate literature, the first studies mainly reported typical cosmopolitan taxa such as L. cohnii (Hilse) D.G.Mann (Round et al. 1990) or L. nivalis (Ehrenb.) D.G.Mann (Round et al. 1990) and taxa described in the early $20^{\text {th }}$ century such as L. gaussii (Heiden) D.G.Mann (Round et al. 1990) and L. suecorum (G.W.F.Carlson) Van de Vijver (Van de Vijver \& Mataloni 2008). Moreover, L. muticopsis (Van Heurck) D.G.Mann (Round et al. 1990) was used as a catch-all taxon for all capitate Luticola specimens, while the non-capitate forms were usually force-fitted into L. mutica (Kütz.) D.G.Mann (Round et al. 1990). This resulted in stretched biogeographical distributions of those species, making them the most widespread in the entire Antarctic Region.

Recently, all sub-Antarctic Luticola species have been the subject of a thorough taxonomic and morphologic revision, in order to unravel the correct diversity of this genus. This resulted in the description of more than 25 new Antarctic Luticola taxa, mainly from the Maritime Antarctic Region and the Antarctic Continent (Van de Vijver et al. 2006, 2011; Kopalová et al. 2011; Levkov et al. 2013; Zidarova et al. 2014; Kohler et al. 2015). Several new taxa were also found in the sub-Antarctic region. In 2002, L. beyensii Van de Vijver et al. (Van de Vijver et al. 2002b) was described from Ile Saint-Paul, whereas L. ledeganckii Van de Vijver (Van de Vijver et al. 2002a), L. robusta Van de Vijver et al. (Van de Vijver et al. 2002a), L. crozetensis Van de Vijver et al. (Levkov et al. 2013), L. ipevii Van de Vijver \& Levkov (Levkov et al. 2013), and L. subcrozetensis Van de Vijver et al. (Levkov et al. 2013), were described from Ile de la Possession, the main island of the Crozet Archipelago.

The present paper continues this revision of the genus Luticola with an analysis of five taxa observed on Ile Amsterdam and Ile Saint-Paul, two islands in the southern Indian Ocean. Two Luticola taxa are described as new based on detailed light and scanning electron microscopy whereas a fifth unidentified taxon could only be found in light micrograph and is illustrated and discussed but due to the lack of sufficient observations, it is still unclear whether it also represents a new species.

\section{Material and methods}

During two short visits (1998 and 1999) and two fieldwork seasons on the volcanic islands Ile Amsterdam $\left(77^{\circ} 30^{\prime} \mathrm{E}, 37^{\circ} 50^{\prime} \mathrm{S}\right)$ and Ile Saint-Paul $\left(77^{\circ} 31^{\prime} \mathrm{E}, 38^{\circ} 43^{\prime} \mathrm{S}\right)$ in 2007 and 2016, more than 300 samples were collected from various habitats including waterbodies, soils and moss vegetations. Both islands are among the most remote islands in the world, situated in the southern Indian Ocean, north of the subAntarctic islands, halfway between South Africa and Australia, and form a separate district within the Terres Australes et Antarctiques Françaises (TAAF). In geological terms, these islands are very young, with the main part of Ile Amsterdam formed during the period 400-200 kyr BP and Ile Saint-Paul being even younger $(<50 \mathrm{kyr})$. More information regarding climate, vegetation and geology can be found in Lebouvier \& Frenot (2007).

Sampling sites were chosen in order to represent a maximum diversity of habitat types. The samples were collected in PVC bottles and fixed with 3\% formalin. In order to determine the moisture content of the sample, the F-value, referring to the F-classification of Jung (1936) was selected as representative for moisture and used for each sample. It is a humidity scale based on water content as follow: FI = 
submerged mosses, FII = free floating mosses, FIII = very wet (water drips from the samples without pressure), FIV = wet (water drips with a slight pressure), FV = quasi-wet (water drips after moderate pressure), FVI = moist (little water produced after high pressure), FVII = quasi-dry (only a few drops of water can be squeezed out), FVIII = dry (contains no water).

Samples were prepared for microscopy analysis following the method described in van der Werff (1955): small parts of the samples were cleaned by adding $37 \% \mathrm{H}_{2} \mathrm{O}_{2}$ and heating to $80^{\circ} \mathrm{C}$ for about $1 \mathrm{~h}$. The reaction was completed by addition of an excessive amount of $\mathrm{KMnO}_{4}$. Following digestion and centrifugation (three times $10 \mathrm{~min}$ at $3700 \times \mathrm{g}$ ), cleaned material was diluted with distilled water to avoid excessive concentrations of diatom valves on the slides. Cleaned diatom valves were mounted in Naphrax ${ }^{\circledR}$. Light microscopy (LM) observations were done at Olympus BX53 microscopes, equipped with Differential Interference Contrast (Nomarski) optics. LM micrographs were taken using Olympus UC30 camera connected to the Cell Sense Standard program. Samples and slides are stored at the BRcollection (Botanic Garden Meise, Belgium). For scanning electron microscopy (SEM), parts of the oxidized suspensions were filtered through a $1 \mu \mathrm{m}$ Isopore ${ }^{\mathrm{TM}}$ polycarbonate membrane filter (Merck Millipore). The stubs were sputter-coated with a platinum layer of $2 \mathrm{~nm}$ and studied in a JEOL JSM7100F SEM microscope at $1 \mathrm{kV}$ (Botanic Garden Meise, Belgium).

Morphological terminology follows Round et al. (1990), Van de Vijver \& Mataloni (2008) and Levkov et al. (2013). The morphology of the new species is discussed based on detailed light and scanning electron microscopy observations and has been compared with known Luticola species using the most current literature: Rumrich et al. (2000), Van de Vijver \& Mataloni (2008), Kopalová et al. (2011), Van de Vijver et al. (2011), Levkov et al. (2013), Zidarova et al. (2014) and Kohler et al. (2015).

\section{Results}

Five Luticola taxa were found in the samples during the survey. Two taxa, L. beyensii and L. subcrozetensis, could be identified using the currently available literature. Based on a morphological analysis, two taxa are described as new species: L. ivetana Chattová \& Van de Vijver sp. nov. and L. vancampiana Chattová \& Van de Vijver sp. nov. Observation of the material in LM revealed the presence of a fifth unknown Luticola taxon with a highly asymmetrical central area. As the taxon could not be found during SEM analysis, we have insufficient data regarding its morphological ultrastructure and therefore the decision was taken not to describe it as new to science.

Class Bacillariophyceae Haeckel emend. Medlin \& Kaczmarska (Medlin \& Kaczmarska 2004)

Subclass Bacillariophycidae D.G.Mann (Round et al. 1990)

Order Naviculales Bessey (Bessey 1907)

Family Diadesmidaceae D.G.Mann (Round et al. 1990)

Genus Luticola D.G.Mann (Round et al. 1990)

Luticola beyensii Van de Vijver, Ledeganck \& Lebouvier

Figs $1-12$

Diatom Research 17: 235-241 (Van de Vijver et al. 2002b).

\section{Type}

ILE SAINT PAUL: TAAF, sub-Antarctica, 16 Dec. 1999, B. Van de Vijver sample $A 9$ (holo-: CAS 220051, California Academy of Science; iso-: slide no. BR-4045, University of Antwerp, Belgium). 


\section{Description}

\section{Light microscopy (Figs 1-10)}

Valves rhombic-lanceolate with clearly convex margins. Larger individuals with more or less rostrate apices, in smaller specimens apices more broadly rounded. Valve dimensions $(n=25)$ : length $14.5-$ $22.0 \mu \mathrm{m}$, width $6.0-8.5 \mu \mathrm{m}$. Axial area relatively narrow, linear. Central area with a large fascia, rarely reaching the valve margins, due to a series of small areolae bordering the central area near the margins. Isolated pore solitary, round, located close to the valve margin, never connected to a stria. Raphe filiform, straight, with simple, bent proximal raphe endings, away from the isolated pore. Terminal raphe fissures clearly hooked. Striae weakly radiate near the central area, becoming more radiate towards the apices, $22-24$ in $10 \mu \mathrm{m}$. Areolae well visible in LM.

\section{Scanning electron microscopy (Figs 11-12)}

Striae composed of 2-4 rounded areolae (Figs 11-12). Occasionally areolae fused within one stria forming transapically enlarged areolae (Fig. 11). Terminal raphe fissures clearly hooked, first deflected towards the side opposite the isolated pore, then hooked into the other side, weakly continuing onto the valve mantle (Fig. 12).

\section{Ecology and associated diatom flora}

Luticola beyensii was found in relatively dry, bare soils and on dry mosses (F-value VII-VIII) on both islands. The samples with $L$. beyensii were dominated by several taxa of the genus Humidophila R.L.Lowe et al. [Humidophila contenta (Grunow) R.L.Lowe et al. (Lowe et al. 2014), Humidophila brekkaensis
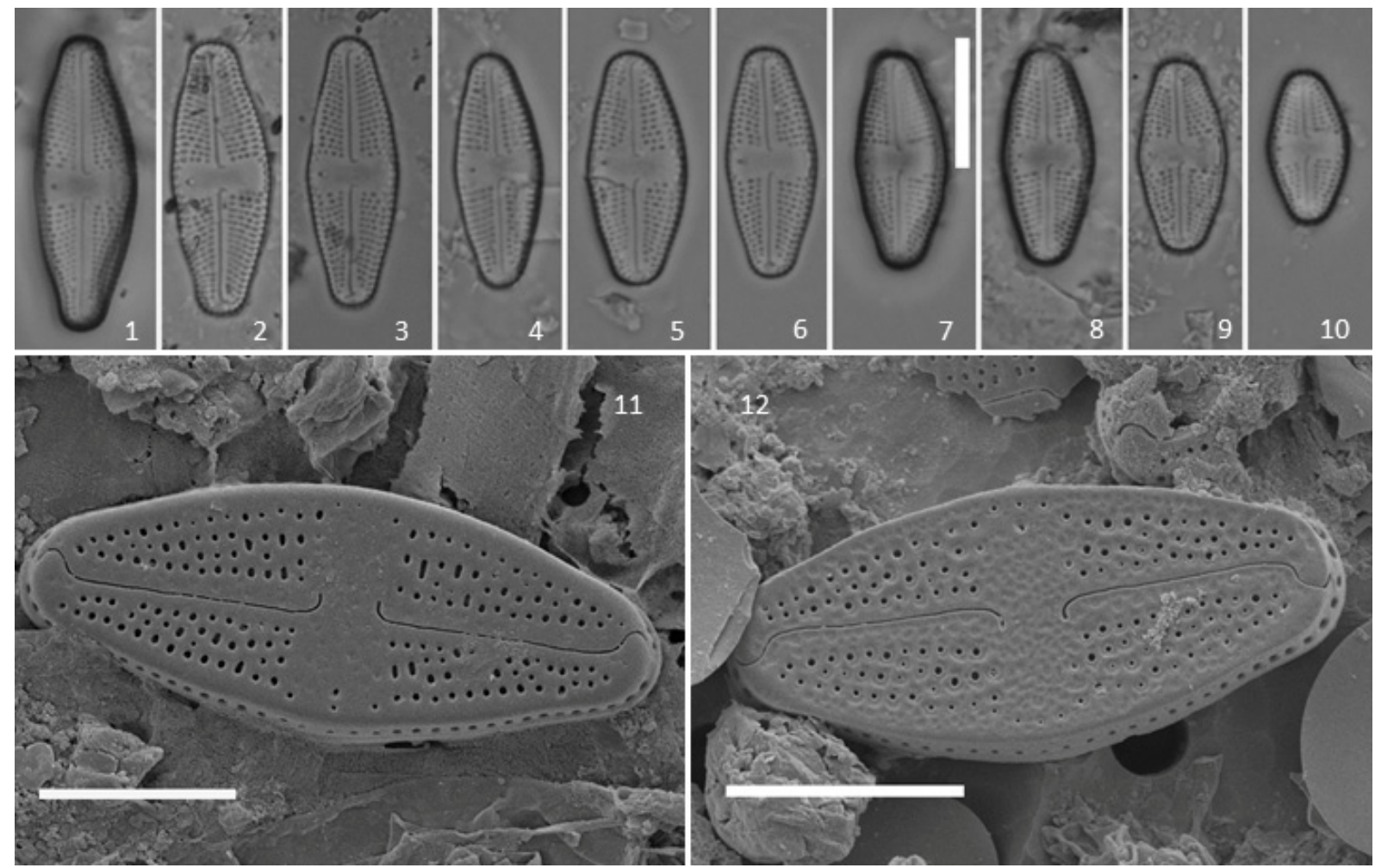

Figs 1-12. Luticola beyensii Van de Vijver et al. Light (LM) and scanning electron micrographs (SEM) of a population from Ile Amsterdam. 1-10. LM of valve face views. 11-12. SEM of external view of entire valve, showing raphe structure, position of the isolated pore and striae structure. Scale bars: 1-10 $=10 \mu \mathrm{m} ; 11-12=5 \mu \mathrm{m}$. 
CHATTOVÁ B. et al., Luticola on Ile Amsterdam and Ile Saint Paul

(J.B.Petersen) R.L.Lowe et al. (Lowe et al. 2014)], and Pinnularia borealis Ehrenb. (Ehrenberg 1843) and Hantzschia amphioxys (Ehrenb.) Grunow (Cleve \& Grunow 1880).

Luticola subcrozetensis Van de Vijver, Kopalová, Zidarova \& Levkov

Figs 13-26

Diatoms of Europe: Diatoms of the European Inland Waters and Comparable Habitats 7: 228, pl. 46 figs 15-31, pl. 47 figs 4-6 (Levkov et al. 2013).

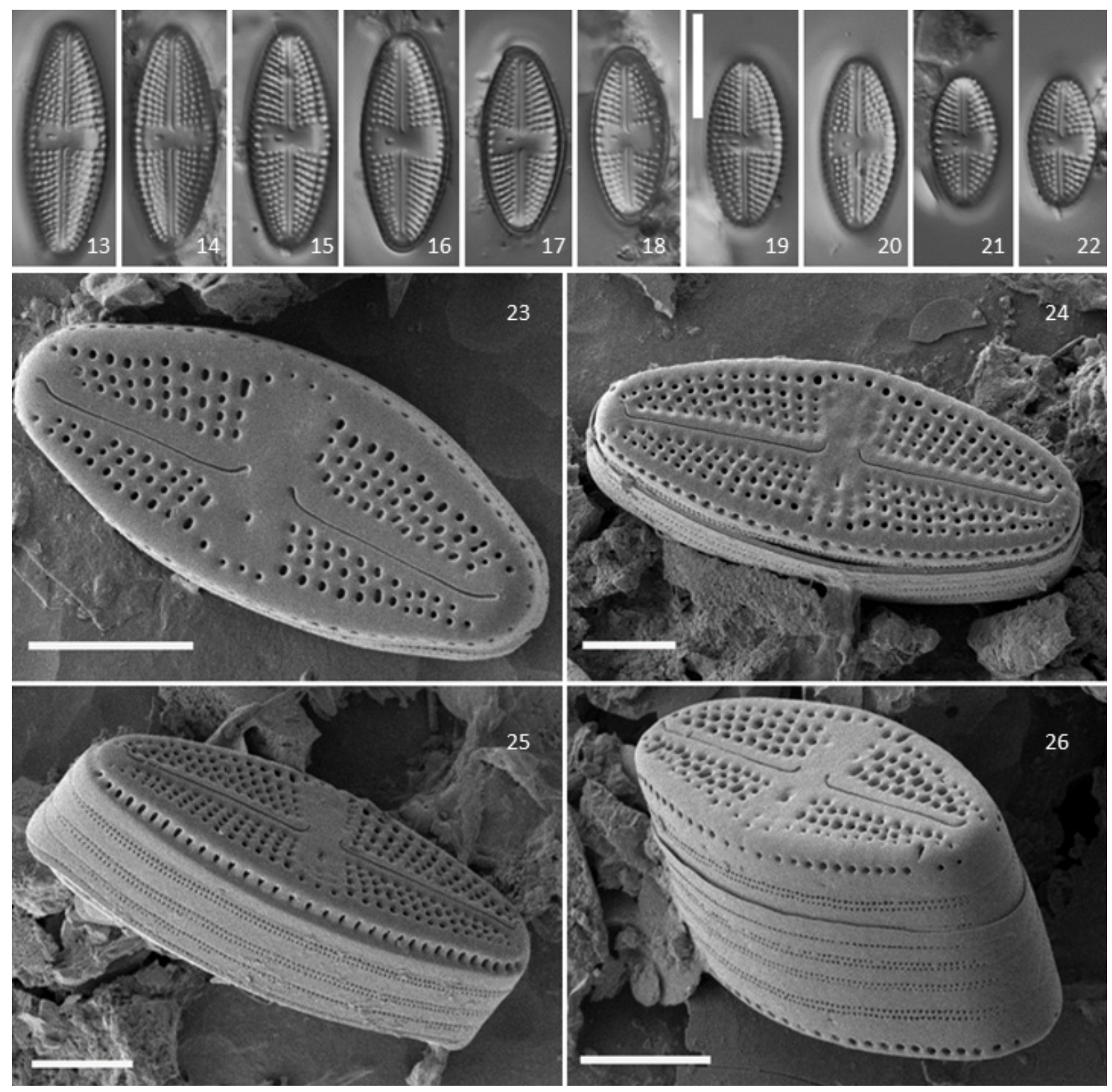

Figs 13-26. Luticola subcrozetensis Van de Vijver et al. Light (LM) and scanning electron micrographs (SEM) of a population from Ile Saint-Paul. 13-22. LM of valve face views. 23-24. SEM of external view showing composition of striae and typical raphe structure. 25-26. SEM girdle view. Scale bars: $13-22=10 \mu \mathrm{m} ; 23-26=5 \mu \mathrm{m}$. 
Type

ILE DE LA POSSESSION: Crozet Archipelago, sub-Antarctica, 5 Dec. 1999, B. Van de Vijver (holo-: slide no. BR-4290; iso-: slides BRMZU9/25, MKNDC 006278/B).

\section{Description}

\section{Light microscopy (Figs 13-22)}

Valves rhombic-lanceolate to elliptic-lanceolate and even elliptic in smaller specimens with clearly convex margins and broadly rounded, non-protracted apices. Valve dimensions $(n=25)$ : length $12-$ $29 \mu \mathrm{m}$, width 7.0-8.5 $\mu \mathrm{m}$. Axial area linear, slightly widening towards apices and central area. Central area bow-tie shaped, wider opposite the isolated pore, bordered by shortened striae on both sides. An isolated pore present in the central area, located halfway between the valve centre and the valve margin. Raphe branches straight, bent away from the isolated pore at both proximal and distal ends. Striae radiate throughout the entire valve, $15-17$ in $10 \mu \mathrm{m}$.

\section{Scanning electron microscopy (Figs 23-26)}

Striae composed of 3-5 small, rounded to slightly elongated areolae at the apices, only 1-2 rounded areolae per stria, extending past the terminal raphe fissures on the valve face (Fig. 23). A single row of rounded areolae present along entire valve mantle, interrupted at apices (Fig. 26). Isolated pore rounded, slightly elongated, not associated with a stria. Central area usually bordered by one, rarely two, series of small, rounded areolae. Raphe branches straight to slightly curved. Proximal raphe endings bent to the side opposite the isolated pore, terminating into weakly developed pores. Terminal raphe fissures bent to the same side as the proximal endings terminating on the valve face, not extending onto the mantle (Fig. 24).

\section{Ecology and distribution}

Luticola subcrozetensis is a typical sub-Antarctic and Maritime Antarctic species. Originally described from Ile de la Possession (Crozet archipelago), the species was also reported from Livingston Island (Zidarova et al. 2016), one of the major South Shetland Islands, located in the southern Atlantic Ocean. The species was recently found in moss samples from Gough Island (Vinšová, unpubl. res.). It was present in samples from both Ile Saint-Paul and Ile Amsterdam.

The largest population was observed in a soil sample collected near the rockhopper penguin rookery of Ile Saint-Paul, at an altitude of $110 \mathrm{~m}$, hidden in cracks in the rocks that border the penguin rookery.

Luticola ivetana Chattová \& Van de Vijver sp. nov.

Figs $27-43$

\section{Etymology}

The new species was named after Mrs. Iveta Chattová, mother of the first author, on the occasion of her $50^{\text {th }}$ birthday.

\section{Type}

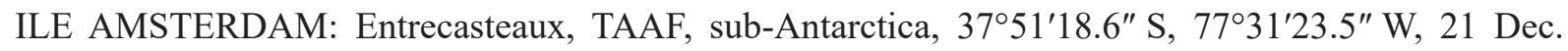
2016, B. Van de Vijver sample W030 (holo-: slide no. BR-4495, Fig. 27; iso-: slide PLP-330; University of Antwerp, Belgium).

\section{Description}

Light microscopy (Figs 27-36) 

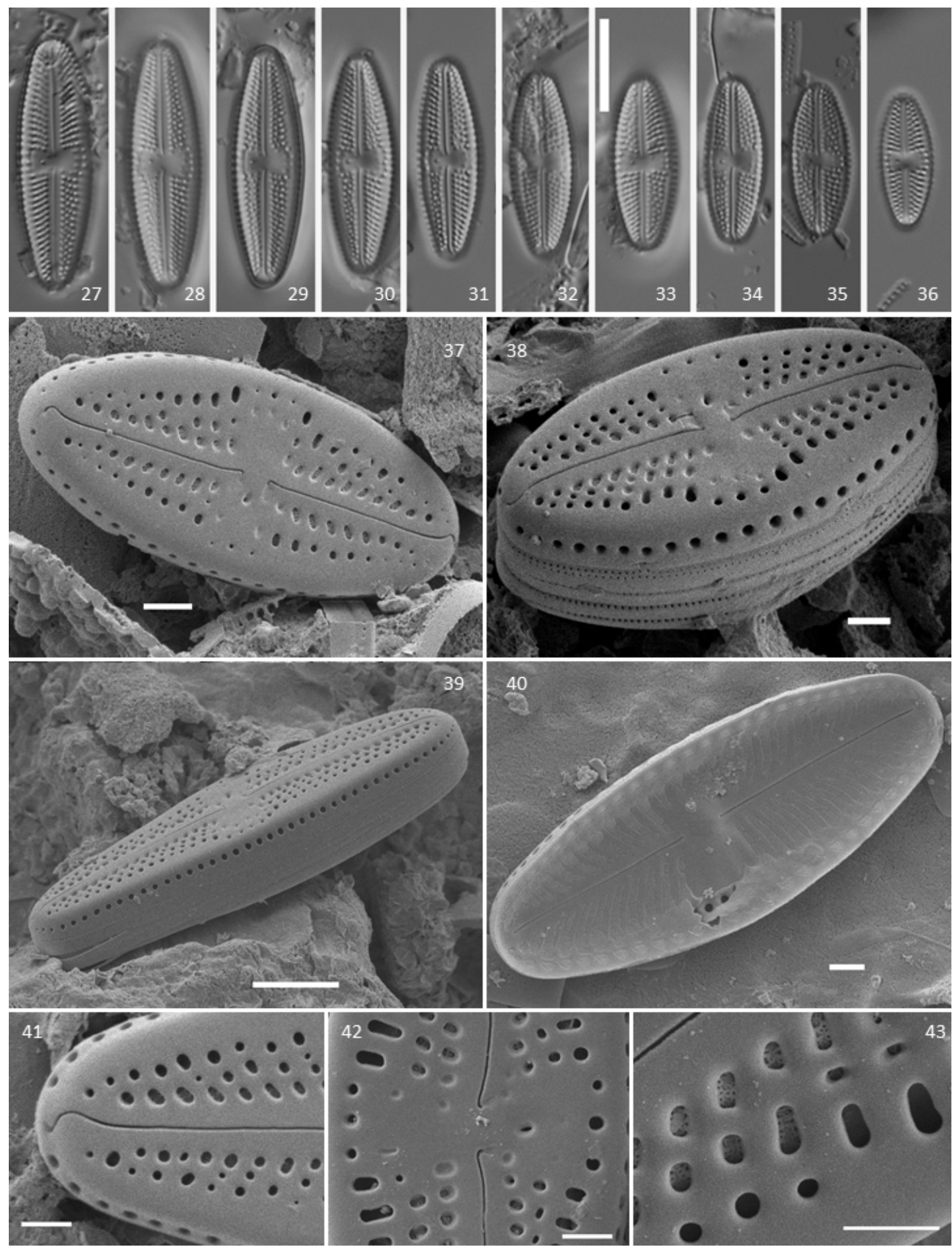

Figs 27-43. Luticola ivetana Chattová \& Van de Vijver sp. nov. Light (LM) and scanning electron micrographs (SEM) from the type population from Entrecasteaux on Ile Amsterdam, B. Van de Vijver sample W030. 27-36. LM of valve face views. 37-38. SEM of valve exterior. 39. SEM girdle view. 40. SEM of valve interior. 41. SEM of external detail of hooked terminal raphe fissures. 42. SEM of external detail view of central area showing the typical deflection of proximal raphe endings. 43. SEM of external detail view of areolae structure. Scale bars: $27-36=10 \mu \mathrm{m} ; 37-38,40-43=1 \mu \mathrm{m} ; 39=5 \mu \mathrm{m}$. 
Valves elliptic-lanceolate with convex margins and broadly rounded, non-protracted apices. Valve dimensions $(\mathrm{n}=50)$ : length $11.0-25.5 \mu \mathrm{m}$, valve width 6.0-7.5 $\mu \mathrm{m}$. Axial area narrow, linear, almost not widening towards the apices and central area. Central area forming a bow-tie shaped stauros. One isolated pore present in the central area, positioned close to the valve centre. Raphe filiform, straight with weakly deflected simple proximal raphe endings and elongated terminal raphe fissures. Striae radiate throughout the entire valve, $16-18$ in $10 \mu \mathrm{m}$.

\section{Scanning electron microscopy (Figs 37-43)}

Striae composed of 2-4 round to elongated areolae, clearly enlarged near the central area and the valve margins (Figs 37, 43). Mantle areolae very large, rounded, never slitlike (Fig. 39). Central area bordered by 1-2 rounded to weakly transapically elongated areolae. Isolated pore elliptic, clearly isolated from the central striae (Fig. 38). Raphe branches straight with short proximal raphe endings bent towards the side with the isolated pore (Fig. 42). Terminal raphe fissures hooked, continuing onto the valve mantle (Fig. 41). Internally, poroids of valve face occluded by hymens forming a continuous strip on each stria. Distinct stauros visible. Internal proximal raphe endings straight, terminating on the edge of the stauros. Distal raphe endings terminating onto small helictoglossae (Fig. 40).

\section{Ecology and distribution}

So far, L. ivetana sp. nov. was observed on Ile Amsterdam only. The type locality where a large population of this new species was observed, was a small crack in a rock face at Entrecasteaux, clearly under the permanent influence of seaspray. A very thin film of water was present in the crack together with wet mud. The sample was taken by scraping off the mud and the water from the crack. Another large population where L. ivetana sp. nov. was found is a lava cavern in the partly collapsed Grand Tunnel, running from the Cratères Vénus to the northern coast. The sample was taken from wet mosses (F-value IV-V), growing on the wall of the cavern, close to the entrance, in a population of Blechnum australe L. The sample was dominated by Ferocia setosa (Greville) Van de Vijver \& Houk (Van de Vijver et al. 2017), Orthoseira verleyenii Van de Vijver (Lowe et al. 2013), Sellaphora barae Van de Vijver \& E.J.Cox (Van de Vijver \& Cox 2013) and various Humidophila species.

Luticola vancampiana Chattová \& Van de Vijver sp. nov.

Figs 44-71

\section{Etymology}

The species is named after Prof. Dr. Karel Van Camp (University of Antwerp, Belgium), to thank him for his efforts in conserving the Van Heurck Collection and his broad interest in diatom research.

\section{Type}

ILE SAINT-PAUL: Conserverie, TAAF, sub-Antarctica, 3842'52.0" S, 77³1'55.5" W, 24 Nov. 2016, B. Van de Vijver sample S029 (holo-: slide no. BR-4496, Fig. 47; iso-: slide PLP-331; University of Antwerp, Belgium).

\section{Description}

\section{Light microscopy (Figs 44-67)}

Valves linear-lanceolate to elliptic-lanceolate, elliptic in the smallest specimens, with protracted, subcapitate to rostrate apices. In smaller specimens, valve ends not as protracted, only subrostrate or obtusely rounded. Initial cells rhombic-lanceolate. Valve dimensions $(\mathrm{n}=35)$ : length $10.0-26.0 \mu \mathrm{m}$, width 5.0-8.5 $\mu \mathrm{m}$. Axial area linear, narrow. Single, rounded isolated pore present in the central area, located halfway between the valve centre and margin, sometimes attached to a stria. Central area wide, bow-tie shaped, bordered on both sides with a series of 3-5 round areolae. Raphe branches straight, 
CHATTOVÁ B. et al., Luticola on Ile Amsterdam and Ile Saint Paul
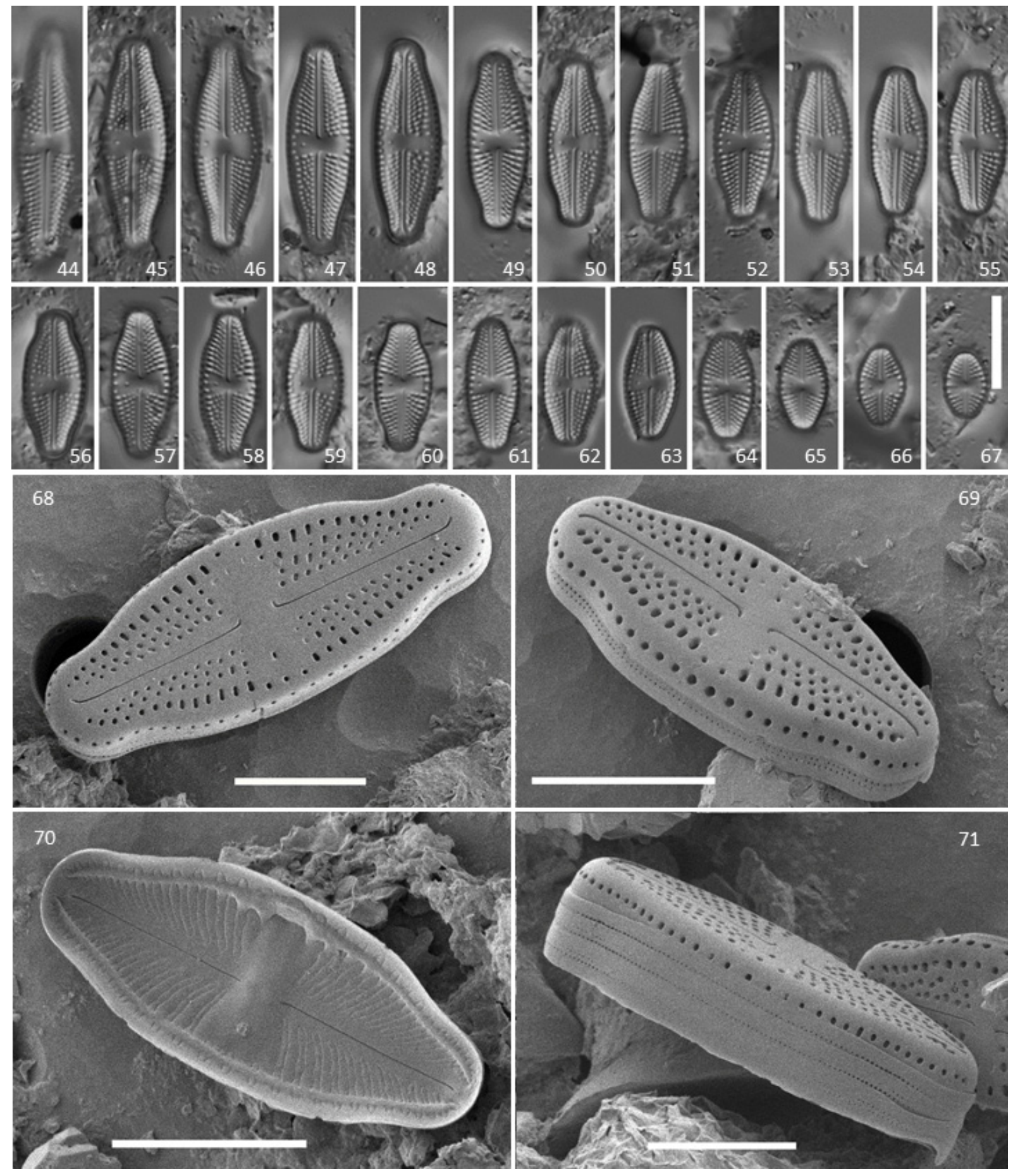

Figs 44-71. Luticola vancampiana Chattová \& Van de Vijver sp. nov. Light (LM) and scanning electron micrographs (SEM) from the type population from Conserverie on Ile Saint-Paul, B. Van de Vijver sample S029. 44-67. LM showing the variation in size and shape of the valve apices. 68-69. SEM of valve exterior. 70. SEM of valve interior. 71. SEM girdle view. Scale bars: $44-6710 \mu \mathrm{m} ; 68-71=5 \mu \mathrm{m}$. 
deflected away from the isolated pore at both proximal and distal ends. Transapical striae radiate throughout, $16-19$ in $10 \mu \mathrm{m}$.

\section{Scanning electron microscopy (Figs 68-71)}

Valve mantle with a single row of round areolae (Fig. 71), interrupted at the apices. Striae composed of 3-4 areolae, 1-2 areolae at the apices. Areolae round to elongated, clearly enlarged and prolonged close to the valve margins (Fig. 68). Internally, areolae occluded by hymens, forming a continuous strip across the valve (Fig. 70). Isolated pore showing an elliptic external opening. Internally, central nodule thickened, expanding into stauros. Isolated pore with semi-lunar opening formed by tonguelike structure. Raphe branches straight. Proximal raphe endings short, deflected to side opposite to the isolated pore. Terminal raphe fissures deflected to the same side as the proximal endings, not extending onto the mantle (Fig. 69). Internally, proximal raphe endings straight, while distally, raphe branches terminating on small helictoglossae.

\section{Ecology and distribution}

So far L. vancampiana sp. nov. was found on both Ile Amsterdam and Ile Saint-Paul. The largest population was found in a wet soil covered by green algae close to the ocean on Ile Saint-Paul. The sampling site is frequently visited by fur seals and penguins, as was visible in the macroremains (feathers, excrements). The sample was almost entirely dominated by the new Luticola species. Other (smaller) populations were found in soil samples collected near penguin rookeries where similar conditions (considerable biotic influence, considerable salinity input) prevailed.

\section{Luticola sp.}

Figs $72-82$

\section{Description}

\section{Light microscopy (Figs 72-82)}

Valves linear-lanceolate to elliptic-lanceolate in smaller specimens, with rounded, non-protracted apices. Valve dimensions $(\mathrm{n}=12)$ : length $10.7-20.5 \mu \mathrm{m}$, width 4.5-6.5 $\mu \mathrm{m}$. Axial area narrow, linear. Central area wide, bow-tie shaped, clearly asymmetrical with the side bearing the isolated pore markedly wider. Isolated pore present in the central area, located halfway between the valve centre and margin. Raphe branches straight, deflected away from the isolated pore at both proximal and distal ends. Transapical striae punctate, radiate throughout the entire valve, 20-24 in $10 \mu \mathrm{m}$.

\section{Remarks}

So far, this species has only been observed with light microscopy. Further studies and SEM observations will be necessary to determine its correct taxonomic position. The species was so far found in only two soil samples (A6 and A7) taken from Ile Saint-Paul. Both samples are dominated by L. beyensii,
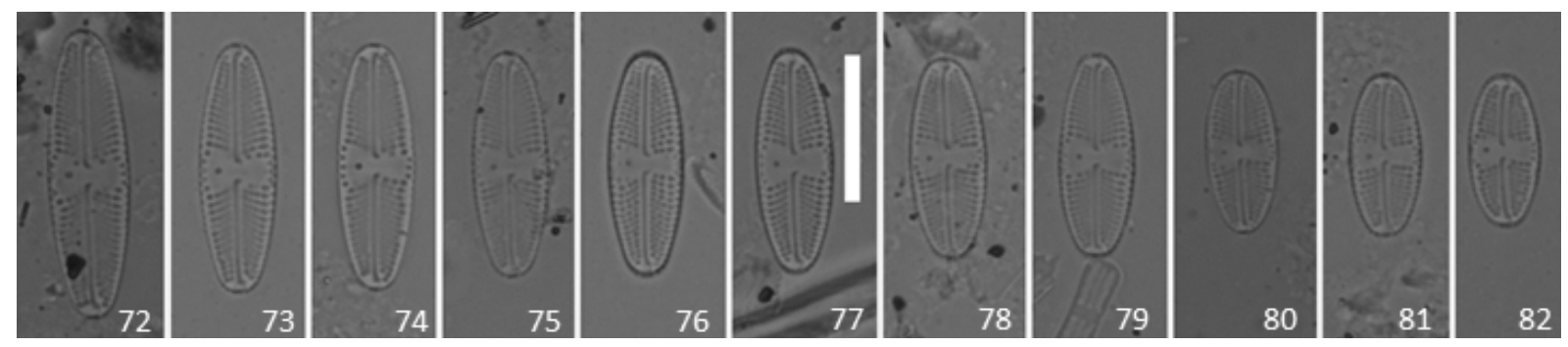

Figs 72-82. Luticola sp. Light micrographs of a population from Ile Saint-Paul. Scale bar: $10 \mu \mathrm{m}$. 
Humidophila brekkaensis, Pinnularia acidicola Van de Vijver \& Le Cohu (Van de Vijver et al. 2002a) and Hantzschia amphioxys.

\section{Discussion}

The genus Luticola is one of the dominant components of the diatom flora in terrestrial habitats on subAntarctic Islands. These habitats show a diverse and very characteristic terrestrial flora with high degree of regional endemism in the entire Antarctic region, as is demonstrated by the large number of endemic taxa in typical terrestrial genera such as Microfissurata Lange-Bertalot et al. (Cantonati et al. 2009), Orthoseira Thwaites (Van de Vijver \& Kopalová 2008, Lowe et al. 2013), Humidophila (Kopalová et al. 2015; Chattová et al., 2017), Hantzschia Grunow (Zidarova et al. 2010) and Muelleria Frenguelli (Frenguelli) (Van de Vijver et al. 2010, 2014).

The morphological and taxonomical analysis of the genus Luticola on Ile Amsterdam and Ile Saint-Paul revealed the presence of two new species. A wide combination of morphological features such as valve outline, shape of the valve apices, shape of the central and axial area, position and shape of the isolated pore, stria pattern and density and raphe and areola structure were used for comparison with all similar taxa known worldwide so far. Sufficient morphological differences were found to justify the separation of both taxa as new to science. The main discriminative features between the new species and their morphologically similar taxa are summarized in Table 1 (Luticola ivetana sp. nov.) and Table 2 (Luticola vancampiana sp. nov.).

Luticola ivetana sp. nov. resembles several Luticola species with elliptic lanceolate valves, however the new species can be easily distinguished by the proximal raphe endings typically bent towards the isolated pore. There are only a few species showing a similar deflection such as L. ledeganckii, L. frequentissima Levkov et al. (Levkov et al. 2013) and L. raynae Zidarova \& Van de Vijver (Van de Vijver et al. 2011). Luticola raynae and L. ledeganckii have typical capitate apices, always lacking in L. ivetana sp. nov. The most similar is L. frequentissima, but the latter species can be differentiated by the shape of the central area, much smaller in L. ivetana sp. nov. and by its stria structure. Luticola frequentissima has transapical striae composed of 4-6 areolae per stria contrary to L. ivetana sp. nov. that has only 2-4 areolae per stria. The two species also differ ecologically, L. ivetana sp. nov. seems to be an aerophilic and most likely even slightly brackish taxon given the habitat in Entrecasteaux where it was found, while L. frequentissima always occurs in freshwater habitats. Luticola mutica and L. imbricata (Bock) Levkov et al. (Levkov et al. 2013) have longer proximal raphe endings curved doubly, a feature lacking in L. ivetana sp. nov. Luticola imbricata additionally differs from the new taxon by the shape of its isolated pore (rounded vs elliptical) and by the apices that are narrowly rounded vs broadly rounded. Luticola mutica does not only differ by the shape and deflection of the raphe endings but also by the different shape of central area and the structure of the striae. Luticola australomutica Van de Vijver (Van de Vijver \& Mataloni 2008) is an Antarctic species described from Deception Island, with a similar valve outline as L. ivetana sp. nov. Nonetheless, both species can be distinguished without any difficulties based on the morphology of the distal and proximal raphe endings. Luticola australomutica has short, almost straight distal raphe fissures, terminating before the last row of areolae, while in L. ivetana sp. nov. the distal raphe fissures are hooked, continuing onto the valve mantle. Additionally, L. australomutica has striae composed of 4-5 areolae contrary to 2-4 areolae per stria in L. ivetana sp. nov.

Smaller specimens of L. ivetana sp. nov. also resemble L. pseudoimbricata Levkov et al. (Levkov et al. 2013) based on their valve shape, but can however be separated by the different shape and deflection of both raphe proximal and distal fissures. Luticola similis Levkov et al. can be differentiated from L. ivetana sp. nov. by the wide and asymmetrical central area, by its lanceolate valve outline and its narrowly rounded valve apices. 


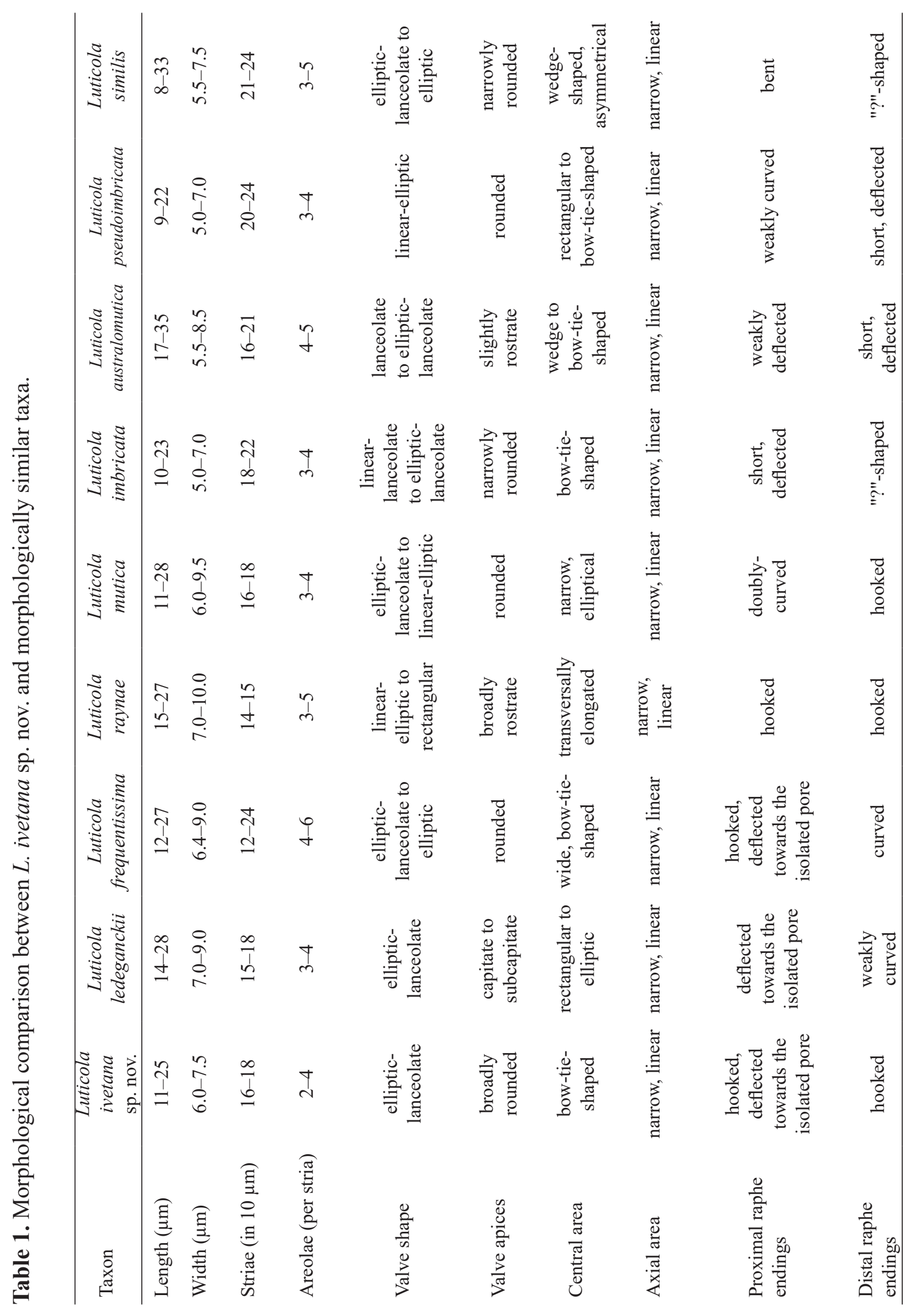




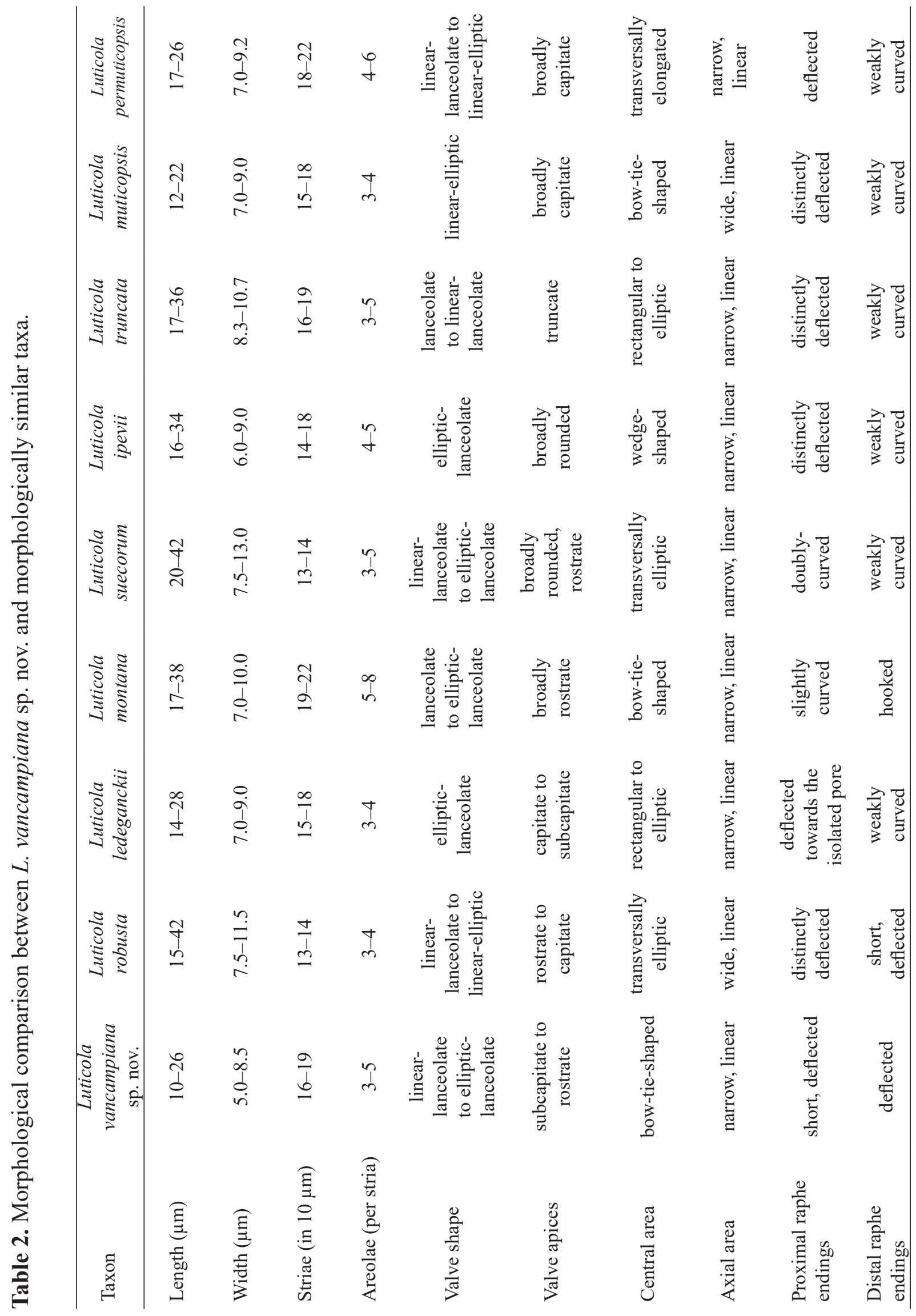


The largest specimens of $L$. vancampiana sp. nov. bear some similarities to L. robusta. However, both taxa significantly differ in stria density (13-14 in $10 \mu \mathrm{m}$ in L. robusta vs 16-19 in $10 \mu \mathrm{m}$ in L. vancampiana sp. nov.). Additionally, L. robusta has a markedly wider axial area. Luticola vancampiana sp. nov. may also resemble L. ledeganckii based on valve shape and stria density. The main difference between these two species can be observed in the direction of proximal raphe endings, which are deflected towards the isolated pore in L. ledeganckii. Luticola montana Levkov et al. (Levkov et al. 2013) has a similar valve shape compared to L. vancampiana sp. nov., but can be easily differentiated from the latter species by its stria and areola density. Luticola montana has finer (19-22 in $10 \mu \mathrm{m})$ striae composed of 5-8 areolae, contrary to L. vancampiana sp. nov. that has only 3-5 areolae per stria. Additionally, the distal raphe fissures in L. montana continue onto the valve mantle, interrupting the row of areolae. Luticola suecorum has similar valve shape and protracted apices. Nevertheless, both species can be hardly confused and are easily distinguished by their valve dimensions and stria density. Luticola suecorum is much larger (20-42 $\mu \mathrm{m}, 7.5-13 \mu \mathrm{m})$ with coarser striae (13-14 in $10 \mu \mathrm{m})$. Additional differences can be observed in the SEM. Luticola suecorum has doubly hooked distal raphe endings that extend onto the valve mantle and an ornamented central area with surface depressions. Luticola ipevii can be differentiated from L. vancampiana sp. nov. by its slender, elongated valve outline and non-protracted, broadly rounded apices. Smaller valves of $L$. vancampiana sp. nov. are similar to L. truncata Kopalová \& Van de Vijver (Kopalová et al. 2009). A clear distinction between the two taxa can be made due to the valve width. Luticola vancampiana sp. nov. $(\mathrm{W}=5.0-8.5 \mu \mathrm{m})$ has narrower valves for any given valve width when compared to L. truncata $(\mathrm{W}=8.5-10.5 \mu \mathrm{m})$. Finally, L. muticopsis and L. permuticopsis Kopalová \& Van de Vijver (Kopalová et al. 2011) have both more capitate apices. Moreover, L. permuticopsis has a higher striae density $(18-22$ in $10 \mu \mathrm{m})$.

The last and unknown species of Luticola, presented here as Luticola sp., is characteristic by its asymmetrical central area, narrow valves and consistently linear-lanceolate outline, a combination of features that is almost never encountered within the genus Luticola. Based on the valve shape and striae density, the most similar species is $L$. frequentissima. Both species can be differentiated by their proximal raphe endings which are deflected towards the isolated pore in L. frequentissima. Moreover, Luticola sp. has slightly narrower valves for any given valve length when compared to $L$. frequentissima. The central area of L. similis Levkov et al. (Levkov et al. 2013) is slightly asymmetrical, but always wider on the side opposite to the isolated pore. Luticola mutica has a more variable valve outline, a narrower central area and coarser striae $(16-18$ in $10 \mu \mathrm{m})$.

\section{Acknowledgements}

The authors would like to thank Drs. Pieter Ledeganck, Prof. Dr. Eric Vidal, Dr. Jennie Whinam, Prof. Dr. Willem De Smet, Dr. Germinal Rouhan and Dr. Damien Ertz for their help during the sampling campaigns, supported by the French Polar Institute (programmes IPEV 136 and 1167). Mrs. B. Chattová benefited from an institutional support of Masaryk University and an ERASMUS scholarship while studying at the Botanic Garden Meise (Belgium) and the University of Antwerp (Belgium).

\section{References}

Bessey C.E. 1907. A synopsis of plant phyla. Nebraska University Studies 7: 275-373.

Cantonati M., Van de Vijver B. \& Lange-Bertalot H. 2009. Microfissurata gen. nov. (Bacillariophyta), a new diatom genus from dystrophic and intermittently wet terrestrial habitats. Journal of Phycology 45: 732-741. https://doi.org/10.1111/j.1529-8817.2009.00683.x

Chattová B., Lebouvier M. \& Van de Vijver B. 2017. Morphological and taxonomical analysis of the terrestrial diatom genus Humidophila (Bacillariophyta) on Ile Amsterdam and Ile Saint-Paul (Southern Indian Ocean). Phytotaxa (in press). 
Cleve P.T. \& Grunow A. 1880. Beiträge zur Kenntniss der arctischen Diatomeen. Kongliga Svenska Vetenskaps-Akademiens Handlingar ser. 417 (2): 1-121.

Ehrenberg C.G. 1843. Verbreitung und Einfluss des mikroskopischen Lebens in Süd-und Nord-Amerika. Abhandlungen der Königlichen Akademie der Wissenschaften zu Berlin 1841: 291-466.

Jung W. 1936. Thecamöben ursprünglicher lebender deutscher Hochmoore. Abhandlungen aus dem Landesmuseum für Naturkdunde zu Münster in Westfalen 7: 1-87.

Kohler T.J., Kopalová K., Van de Vijver B. \& Kociolek J.P. 2015. The genus Luticola D.G.Mann (Bacillariophyta) from the McMurdo Sound Region, Antarctica, with the description of four new species. Phytotaxa 208:103-134. https://doi.org/10.11646/phytotaxa.208.2.1

Kopalová K., Elster J., Nedbalová L. \& Van de Vijver B. 2009. Three new terrestrial diatom species from seepage areas on James Ross Island (Antarctic Peninsula Region). Diatom Research 24: 113-122. https://doi.org/10.1080/0269249X.2009.9705786

Kopalová K., Nedbalová L., de Haan M. \& Van de Vijver B. 2011. Description of five new species of the diatom genus Luticola (Bacillariophyta, Diadesmidaceae) found in lakes of James Ross Island (Maritime Antarctic Region). Phytotaxa 27: 44-60. https://doi.org/10.11646/phytotaxa.27.1.5

Kopalová K., Kociolek J.P., Lowe R.L., Zidarova R. \& Van de Vijver B. 2015. Five new species of the genus Humidophila (Bacillariophyta) from the Maritime Antarctic Region. Diatom Research 30: 117-131. https://doi.org/10.1080/0269249X.2014.998714

Lebouvier M. \& Frenot Y. 2007. Conservation and management in the French sub-Antarctic islands and surrounding seas. Papers and Proceedings of the Royal Society of Tasmania 141: 23-28.

Levkov Z., Metzeltin D. \& Pavlov A. 2013. Diatoms of Europe: Diatoms of the European Inland Waters and Comparable Habitats. Vol. 7. Koeltz Scientific Books, Köningstein.

Lowe R.L., Kociolek J.P. \& Van de Vijver B. 2013. Two new Orthoseira species (Bacillariophyceae) from lava tubes on Île Amsterdam and Big Island (Hawaii). Phytotaxa 111: 39-52. https://doi.org/10.11646/phytotaxa.111.1.3

Lowe R.L., Kociolek J.P., Johansen J.R., Van de Vijver B., Lange-Bertalot H. \& Kopalová K. 2014. Humidophila gen. nov., a new genus for a group of diatoms (Bacillariophyta) formerly within the genus Diadesmis: species from Hawai'i, including one new species. Diatom Research 29: 351-360. https://doi.org/10.1080/0269249X.2014.889039

Medlin L.K. \& Kaczmarska I. 2004. Evolution of the diatoms: V. Morphological and cytological support for the major clades and a taxonomic revision. Phycologia 43: 245-270. https://doi.org/10.2216/i0031-8884-43-3-245.1

Round F.E., Crawford R.M. \& Mann D.G. 1990. The Diatoms: Biology and Morphology of the Genera. Cambridge University Press, Cambridge.

Rumrich U., Lange-Bertalot H. \& Rumrich M. 2000. Diatoms of the Andes. From Venezuela to Patagonia/Tierra del Fuego and two additional contributions. Iconographia Diatomologica 9: 1-673.

Tyler P.A. 1996. Endemism in freshwater algae, with special reference to the Australian region. Hydrobiologia 336: 127-135. https://doi.org/10.1007/BF00010826

Van de VijverB.\& Cox E.J. 2013. New and interesting small-celled naviculoid diatoms (Bacillariophyceae) from a lava tube cave on Île Amsterdam (TAAF, southern Indian Ocean). Cryptogamie, Algologie 34: 37-47. https://doi.org/10.7872/crya.v34.iss1.2013.37

Van de Vijver B. \& Kopalová K. 2008. Orthoseira gremmenii, a new aerophilic diatom from Gough Island (southern Atlantic Ocean). Cryptogamie, Algologie 29: 105-118. 
Van de Vijver B. \& Mataloni G. 2008. New and interesting species in the genus Luticola D.G. Mann (Bacillariophyta) from Deception Island (South Shetland Islands). Phycologia 47: 451-467. https://doi.org/10.2216/07-67.1

Van de Vijver B., Frenot Y. \& Beyens L. 2002a. Freshwater diatoms from Île de la Possession (Crozet Archipelago, Subantarctica). Bibliotheca Diatomologica 46: 1-412.

Van de Vijver B., Ledeganck P. \& Lebouvier M. 2002b. Luticola beyensii sp. nov., a new aerophilous diatom from ile Saint Paul (Indian Ocean, TAAF). Diatom Research 17: 235-241. https://doi.org/10.1080/0269249X.2002.9705541

Van de Vijver B., Van Dam H. \& Beyens L. 2006. Luticola higleri sp. nov., a new diatom species from King George Island (South Shetland Islands, Antarctica). Nova Hedwigia 82: 69-79. https://doi.org/10.1127/0029-5035/2006/0082-0069

Van de Vijver B., Mataloni G., Stanish L. \& Spaulding S.A. 2010. New and interesting species of the genus Muelleria (Bacillariophyta) from the Antarctic region and South Africa. Phycologia 49 (1): 22-41. https://doi.org/10.2216/09-27.1

Van de Vijver B., Zidarova R. \& de Haan M. 2011. Four new Luticola taxa (Bacillariophyta) from the South Shetland Islands and James Ross Island (Maritime Antarctic Region). Nova Hedwigia 92: 137-158. https://doi.org/10.1127/0029-5035/2011/0092-0137

Van de Vijver B., Zidarova R. \& Kopalová K. 2014. New species in the genus Muelleria (Bacillariophyta) from the Maritime Antarctic Region. Fottea 14: 77-90. https://doi.org/10.5507/fot.2014.006

Van de Vijver B., Chattová B., Lebouvier M. \& Houk V. 2017. Ferocia gen. nov., a new centric diatom genus (Bacillariophyceae) from the sub-Antarctic region. Phytotaxa 332: 22-30. https://doi.org/10.11646/phytotaxa.332.1.2

Van der Werff A. 1955. A new method for cleaning and concentrating diatoms and other organisms. Verhandlungen der Internationalen Vereinigung für theoretische und angewandte Limnologie 12: 276277.

Zidarova R., Van de Vijver B., Quesada A. \& de Haan M. 2010. Revision of the genus Hantzschia (Bacillariophyceae) on Livingston Island (South Shetland Islands, Southern Atlantic Ocean). Plant Ecology and Evolution 143: 318-333. https://doi.org/10.5091/plecevo.2010.402

Zidarova R., Levkov Z. \& Van de Vijver B. 2014. Four new Luticola taxa (Bacillariophyta) from Maritime Antarctica. Phytotaxa 170: 155-168. https://doi.org/10.11646/phytotaxa.170.3.2

Zidarova R., Kopalová K. \& Van der Vijver B. 2016. Diatoms from the Antarctic region: maritime Antarctica. Iconographia Diatomologica 24: 1-504. 
Manuscript received: 12 July 2017

Manuscript accepted: 17 October 2017

Published on: 22 December 2017

Topic editor: Frederik Leliaert Ph.D., Koen Martens

Desk editor: Alejandro Quintanar

Printed versions of all papers are also deposited in the libraries of the institutes that are members of the EJT consortium: Muséum national d'Histoire naturelle, Paris, France; Botanic Garden Meise, Belgium; Royal Museum for Central Africa, Tervuren, Belgium; Natural History Museum, London, United Kingdom; Royal Belgian Institute of Natural Sciences, Brussels, Belgium; Natural History Museum of Denmark, Copenhagen, Denmark; Naturalis Biodiversity Center, Leiden, the Netherlands; Museo Nacional de Ciencias Naturales-CSIC, Madrid, Spain; Real Jardín Botánico de Madrid CSIC, Madrid, Spain. 